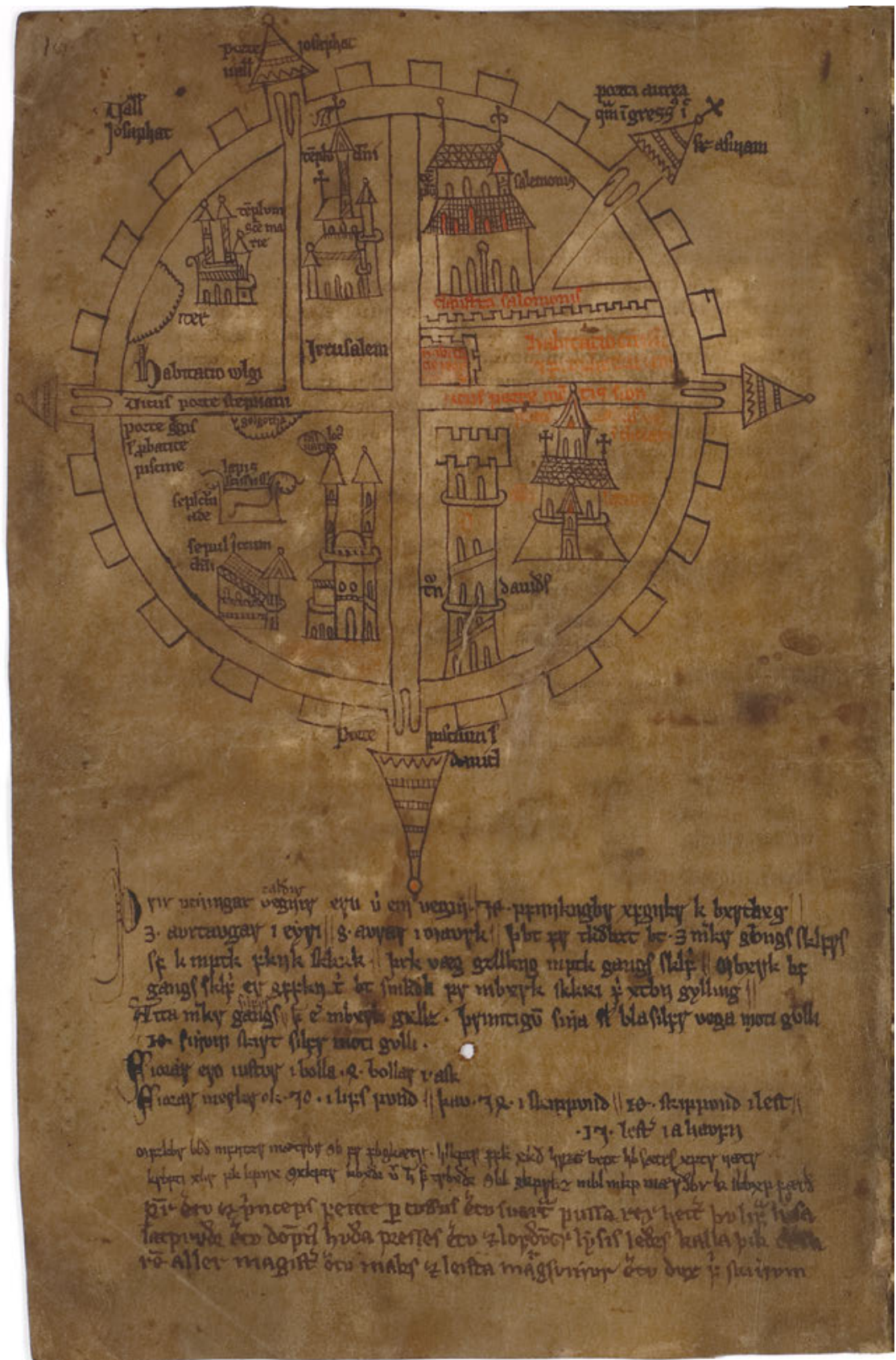

Fig. 20.1: Plan of Jerusalem. Icelandic manuscript fragment, early fourteenth century (AM 732b 4to, fol. 8v), The Arnamagnæaen manuscript collection, Copenhagen.

D Open Access. (C) 2021 Kristin B. Aavitsland, published by De Gruyter. (c) BY-NC-ND This work is licensed under the Creative Commons Attribution-NonCommercial-NoDerivatives 4.0 International License.

https://doi.org/10.1515/9783110639438-021 
Kristin B. Aavitsland

Chapter 20

\section{Civitas Hierusalem famosisima: The Cross, the Orb, and the History of Salvation in the Medieval North}

Three vernacular manuscripts from Iceland and Norway, all dating from the first half of the fourteenth century, contain a circular, schematic map of Jerusalem. This geometrical mode of representing the holy city seems to have emerged in Flanders during the first decades of the twelfth century. Here, geometrical Jerusalem maps were composed during the heyday of the crusader states in the Levant, at a point in history when the earthly Jerusalem had gained a new (political) interest to Latin Christianity and the victorious first crusade was still a living memory. The historical context of the Old Norse Jerusalem maps is a different one. Why did the twelfth-century crusader maps of Jerusalem still matter in the early fourteenth century? And why did they matter to people in the north, at the very edge of the Christian world? This chapter aims to shed some light on these questions through a three-step analysis: Firstly, I shall examine some peculiarities in the visual language of the northern maps that make them stand out from their continental predecessors. Secondly, I will discuss the maps' immediate textual surroundings in the three Old Norse manuscripts. Thirdly, I demonstrate how the maps and their surrounding texts are related and mutually connected rhetorical arguments.

\section{Picturing Jerusalem in Old Norse Manuscripts}

The three circular Jerusalem maps in Old Norse manuscripts (AM 544 4to, AM 732b 4to, and AM 736 I 4to) have a common overall design and all share significant features (Figs. 20.1-20.3). The design is clearly modelled on the "crusader map" typos, of which a dozen are preserved in continental manuscripts from the twelfth century, predating the Old Norse versions by two hundred years. ${ }^{1}$ In some of the Flemish

\footnotetext{
1 Rudolf Simek, "Hierusalem civitas famosissima: Die erhaltenen Fassungen des hochmittelalterlichen Situs Jerusalem,” Codices Manuscripti. Zeitschrift für Handschriftenkunde 12 (1992), 121-53. In his overview, Simek lists fourteen medieval Jerusalem maps altogether, including schematic maps the design of which differs from the Icelandic ones. In this context, I find it more useful to restrict the group to
}

Kristin B. Aavitsland, Professor of Medieval Studies, MF Norwegian School of Theology, Religion and Society, Oslo, Norway 


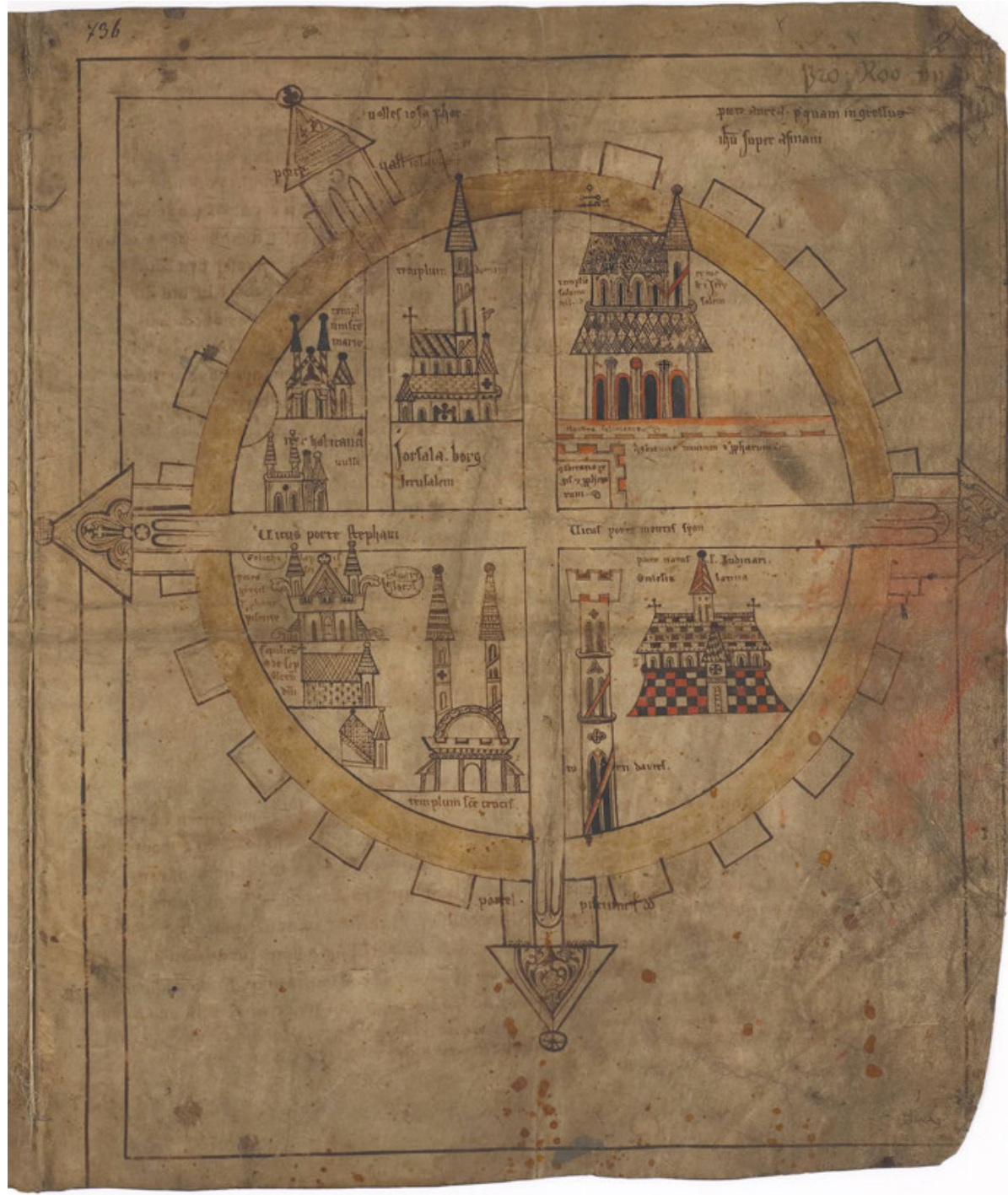

Fig. 20.2: Plan of Jerusalem. Icelandic manuscript fragment, early fourteenth century (AM 736 I 4to, fol. 2r), The Arnamagnæaen manuscript collection, Copenhagen.

those sharing the same figural features. Simek omitted the Jerusalem map in Uppsala ms C691, described by Milka Levy-Rubin, "The Rediscovery of the Uppsala Map of Crusader Jerusalem,” Zeitschrift des Deutschen Palästina Vereins 111 (1995). See also Jay Rubenstein, "Heavenly and Earthly Jerusalem: The View from Twelfth-Century Flanders," in Visual Constructs of Jerusalem, ed. Bianca Kühnel, et al. (Turnhout: Brepols, 2014). On the patristic and early medieval origin of the circular Jerusalem map, see Milka Levy-Rubin, "From Eusebius to the Crusader Maps: The Origin of the Holy Land Maps," in Visual Constructs of Jerusalem, ed. Bianca Kühnel, et al. (Turnhout: Brepols, 2014). 
manuscripts, the circular Jerusalem maps illustrate chronicles about the first crusade and the Frankish conquest of Jerusalem in 1099 (Fig. 20.4). ${ }^{2}$ In the three Icelandic manuscripts, on the other hand, the immediate crusading context is gone. Here, in these books compiled more than one century after the Franks' loss of Jerusalem, at least one generation after the fall of Acre (the last Western stronghold in the Terrasanta), and not long after the transfer of the papal See from Rome to Avignon, the Jerusalem maps are integrated into texts presenting general encyclopaedic knowledge. The manuscripts seem to originate from the Benedictine monasteries in Northern Iceland, although nothing definite is known of their production. ${ }^{3}$

At first glance, the Icelandic Jerusalem maps follow their twelfth-century prototypes closely: the direction is orientated, the city plan is rendered in the form of a perfect circle, and within the crenellated city walls the most significant pilgrimage sites are indicated. All three maps substantially include the same Latin legends and the same sites - the only vernacular legend in the Icelandic maps is found in AM 736 I 4to, where the name of the city is given twice: Jorsala borg/Jerusalem (Fig. 20.2). Churches and monuments are distributed according to convention in each of the four quarters of the city, reflecting to a certain extent the real topography of Jerusalem's Old City. Still, symbolic form clearly trumps topographic reality in all the circular Jerusalem maps. The very choice of the circle as a fundamental design for the city indicates a conceptual connection between Jerusalem and the totality of terrarum orbis, the inhabited world as a whole. ${ }^{4}$ Hence, the holy city, navel of the world, becomes a visual metonym for the entire world, a quality which is enforced by the intentional three-dimensionality of the circular Jerusalem designs. As Mary Carruthers has convincingly shown, medieval geometric diagrams were intended to be "read" as three-dimensional figures. The circular Jerusalem maps should thus be conceived of as hemispheres viewed from above, with the crenellated city walls "popped up" imaginatively above the circular "ground" of the city itself. ${ }^{5}$

Despite evident similarities with the twelfth-century Jerusalem maps, the Icelandic exemplars also exhibit some conspicuous deviations. The street grid in the twelfthcentury continental Jerusalem maps tends to echo the most common and best established imago mundi of medieval learning: the T-O map, a representation of the three

2 For instance St Omer, Bibliothèque municipale, cod. 776; Leiden, Bibliotheck der Rijksuniversiteit, cod. Voss.Lat.F 31; Uppsala, Universitetsbiblioteket, ms C691; Brüssel, Bibliothèque Royale Albert 1er, cod. 9823-24; Paris, Bibliothèque Nationale, cod. Lat. 8865; The Hague, Koniklijke Bibliotheek, Cod. 75 F5.

3 Karl G. Johansson, "Om nordisk och lärt hos de tidiga benediktinarna på Island,” in Tidlige klostre i Norden før 1200. Et symposium, ed. Lars Bisgaard and Tore Nyberg (Odense: Syddansk Universitetsforlag, 2006).

4 Cf. Chapter 1 (Kristin B. Aavitsland), 14-17.

5 Mary Carruthers in her not yet published lectures on geometry and eloquence, "Cognitive Geometries: Using Diagrams in the Middle Ages,” (2017). I wish to thank Mary Carruthers for her thoughtful comments on the overall design of the circular Jerusalem maps. 


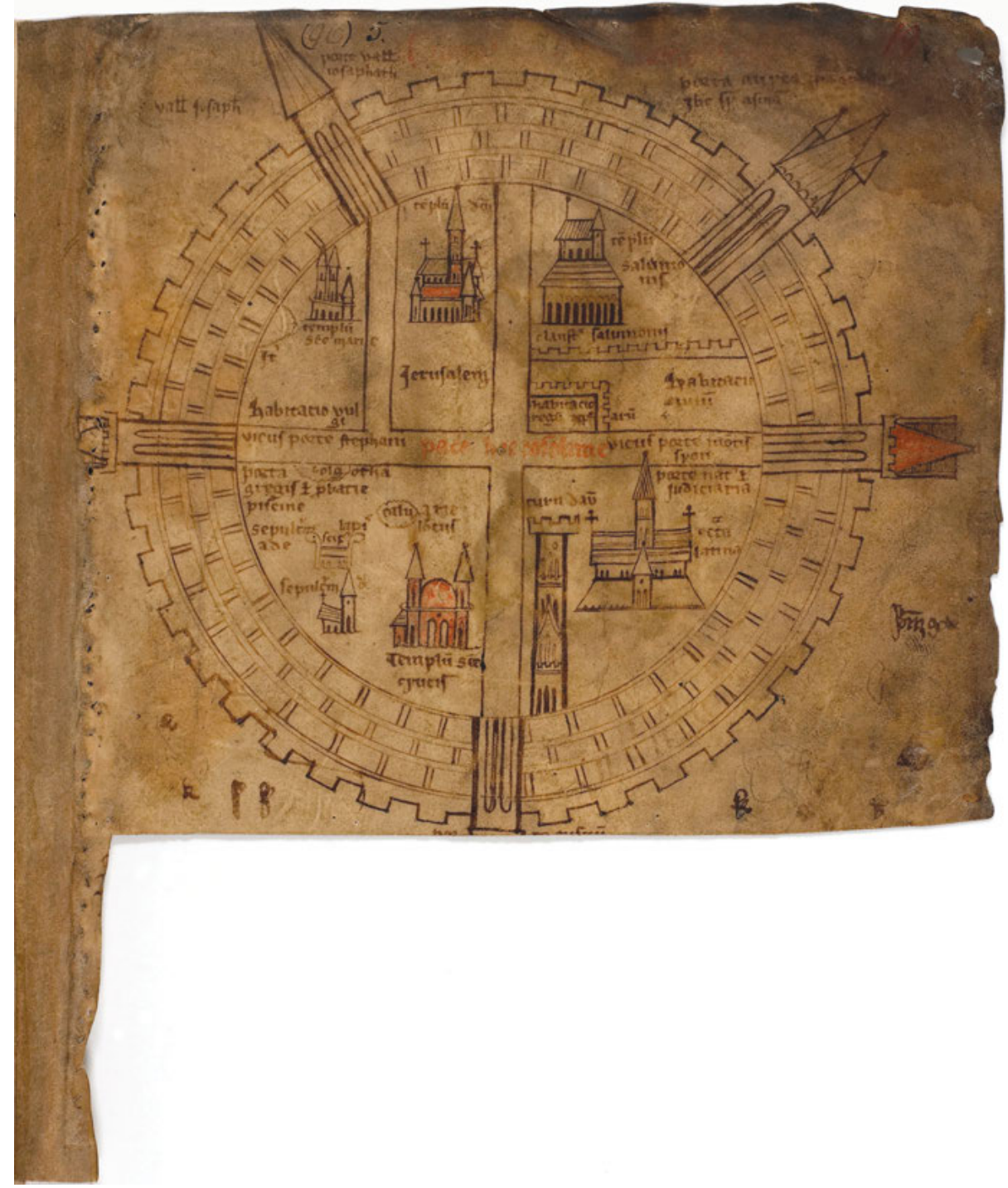

Fig. 20.3: Plan of Jerusalem. Icelandic manuscript, early fourteenth century (AM 544 4to, Hauksbók, fol. 19r), The Arnamagnæaen manuscript collection, Copenhagen. 
continents of the world, according to Isidore of Seville's description (Fig 20.4). ${ }^{6}$ In the Icelandic maps, moreover, the street grid is rendered with a different emphasis - the four city quarters are represented as equal parts, explicitly divided by a cruciform crossroads [cardo/decumanus]. Hence, the city plan takes on another highly symbolic form: it is a cross, inscribed by an orb, thus hinting at the idea of Christus pantocrator, Christ's universal dominion. The tendency to favour the cross form at the expense of topographic reality is striking in the three Icelandic maps. In all of them, and in none of the continental ones, the precinct of the Haram al-Sharif or Temple Mount is incorrectly divided to achieve a distinctly cruciform city plan. The upper part of the cardo thus separates the templum domini (the crusaders' interpretation of the Dome of the Rock) from the templum salumonis (the corresponding interpretation of the Al-Aqsa Mosque). Moreover, the Icelandic exemplars represent the city in splendid isolation: no attempts are made to render the surrounding topography, the roads, mountains, lakes, and rivers found in the twelfth-century versions, where the biblical sites in the city's immediate environment are clearly indicated, and in some cases armed horsemen (crusaders?) and pilgrims populate the landscape. In these twelfth-century continental maps, the city itself tends to be seen from the perspective of those pilgrims and horsemen, so to speak: the walls and gates are rendered as seen from outside. The gates in The Hague KB ms 75 F, for instance, are facing outward, so that travellers may enter via those roads drawn to approach them (Fig. 20.4). Contrary to this manner, the three Icelandic maps represent the walls and gates as facing in towards the city, suggesting an enclosed space and a perspective from within. This pictorial means of rendering the holy city as a three-dimensional closure is in accordance with traditional, foursquare representations of St John's vision of the heavenly Jerusalem, as in the many manuscripts illustrating the eighth-century Spanish monk Beatus of Liebana's commentary of the Book of the Apocalypse. ${ }^{7}$

There are yet some other features distinguishing the Icelandic Jerusalem maps from their continental predecessors. First, the Icelandic Jerusalem maps refer solely to sites connected with biblical history: to the dignity of Israel's kings and to the passion and resurrection of Christ. This is in contrast to the twelfth-century maps, which also include legends referring to mundane sites like the market square and the money exchange [forum rerum venalium; cambium monete]. Second, the drawings of buildings in the three Icelandic maps also vary from the other maps in this group. Unlike the earlier maps, which mostly render the circular structure of the Anastasis rotunda as a ground plan seen from above, the Icelandic maps all depict the Templum sanctae crucis (Church of the Holy Sepulchre) as a domed building with twin towers. Moreover, the Icelandic representations of the templum domini (Dome of

6 Anne-Dorothee von den Brincken, Fines Terrae: Die Enden der Erde und der vierte Kontinent auf mittelalterlichen Weltkarten, MGH (1992), 45-54.

7 Cf. Carruthers, “Cognitive Geometries.” 


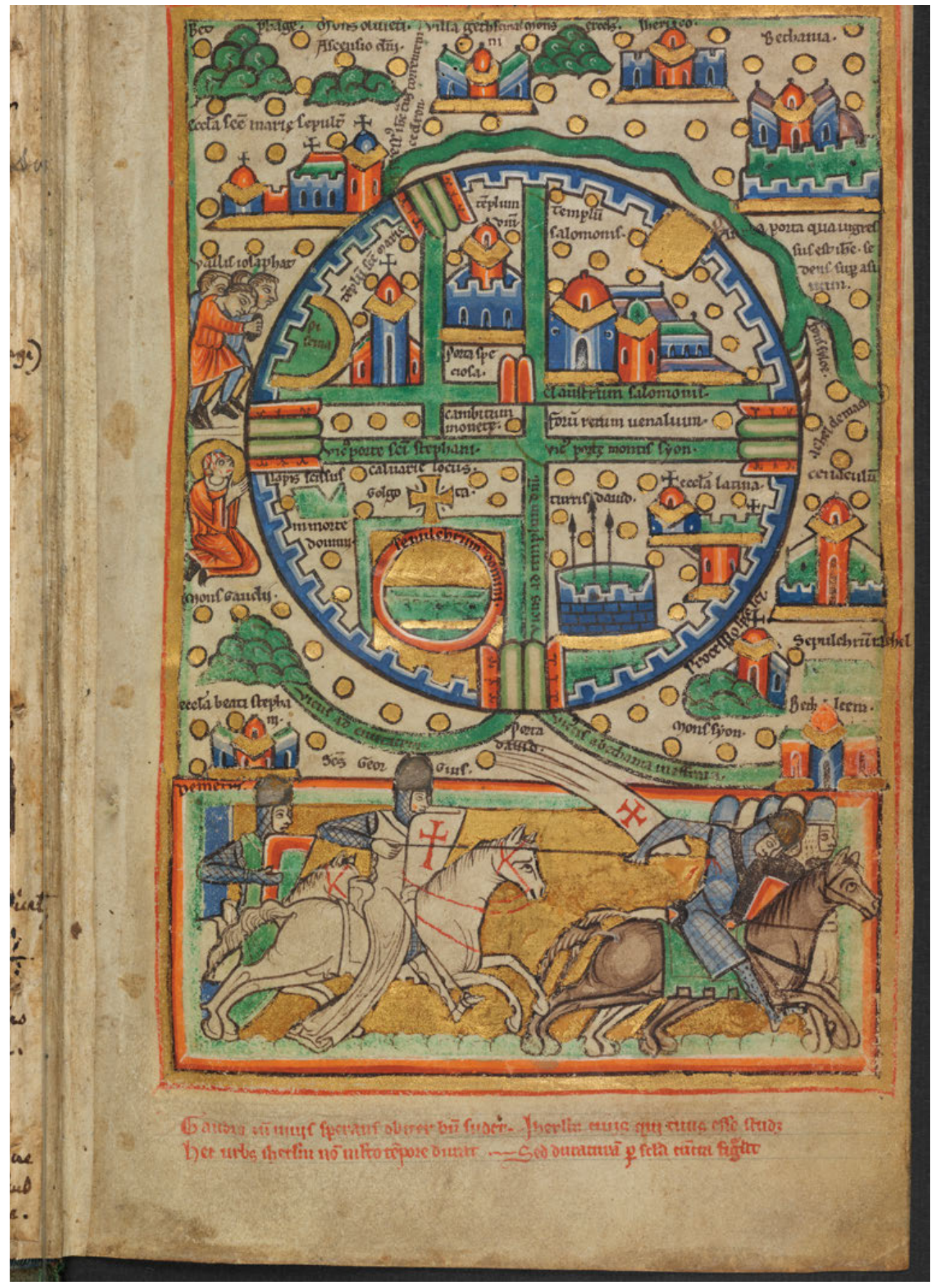

Fig. 20.4: Plan of Jerusalem (“Crusader map”), Frakish manuscript fragment (psalter?), mid twelfth century (ms KB 76 F 5, fol. 1r). Koninklijke Bibliotheek, National Library of the Netherlands, The Hague. 


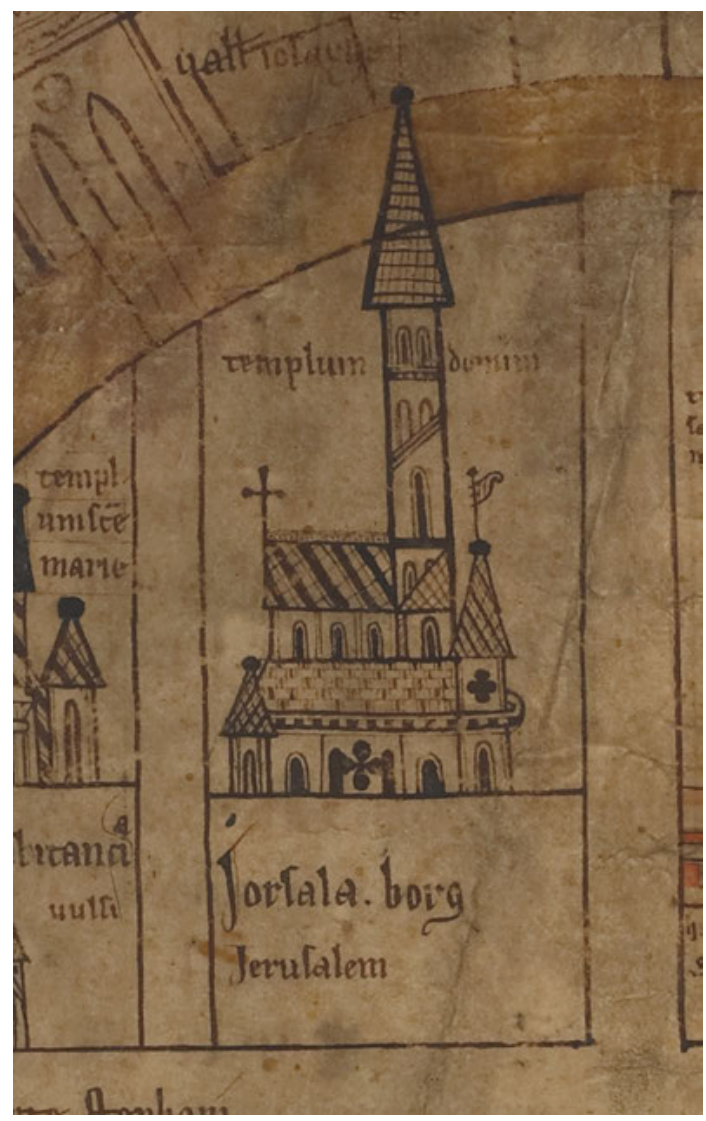

Fig. 20.5: Templum Domini. Detail of the Jerusalem plan in AM 736 I 4to, fol. 2r. The Arnamagnæaen manuscript collection, Copenhagen. the Rock) also differ from the earlier maps, which all tend to depict it according to reality, as a centralized, vaulted building. In the Icelandic maps, the dome is lacking and the templum domini is represented as a basilica-like structure with multiple towers (Fig. 20.5). Remarkably, all representations of architecture in the Icelandic maps show close stylistic and iconographical similarities to architectural elements in Scandinavian church art from the thirteenth and fourteenth centuries. The buildings represented in the maps look very much like two-dimensional versions of the peculiar type of wooden church models still found in some Norwegian parish churches and preserved in museums (Fig. 20.6). During the thirteenth and fourteenth centuries, this particular form of micro-architecture served as tabernacles for the sacrament and canopies above sculptures of the mother of God or other saints. ${ }^{8}$ The same kind of stylized, polychrome, architectural elements are seen in several of the remarkably wellpreserved altar panels originating from Norway and Iceland in the same period. In the altar panels, the architectural elements always surround the figures of holy persons in their celestial glory. ${ }^{9}$ Even in sculpture, we find the same type of achitectural representation on the royal thrones of the Virgin and St Olav. Hence, in rural Norway and Iceland, this kind of urban architecture clearly belonged to the City of God, the heavenly Jerusalem.

8 Kaja Kollandsrud, “A Perspective on Medieval Perception in Norwegian Church Art," in Paint \& Piety, ed. Noëlle L.W. Streeton and Kaja Kollandsrud (London - Oslo: Archetype, 2014); Elisabeth Andersen, "Madonna Tabernacles in Scandinavia c.1150-c.1350," Journal of the British Archaeological Association 168, no. 1 (2015).

9 See for instance the altar panels from Tingelstad in Eastern Norway and Möðruvellir in Iceland. 
At this point, we may conclude that the visual characteristics of the Icelandic Jerusalem maps favour Christological and eschatological dimensions. Turning to their manuscript contexts, the motivation for copying Jerusalem maps in fourteenth-century Iceland may become clearer.

\section{The Manuscript Contexts of the Icelandic Jerusalem Maps}

The three northern manuscripts containing Jerusalem maps belong to a cluster of Old Norse encyclopaedic texts with a shared transmission history, as Rudolf Simek has shown in his vast work Altnordische Kosmographie (1990). The texts in this cluster deal with topics such as cosmology, astronomic constellations, calendar calculations, meteorology, lands, animals, and plants,

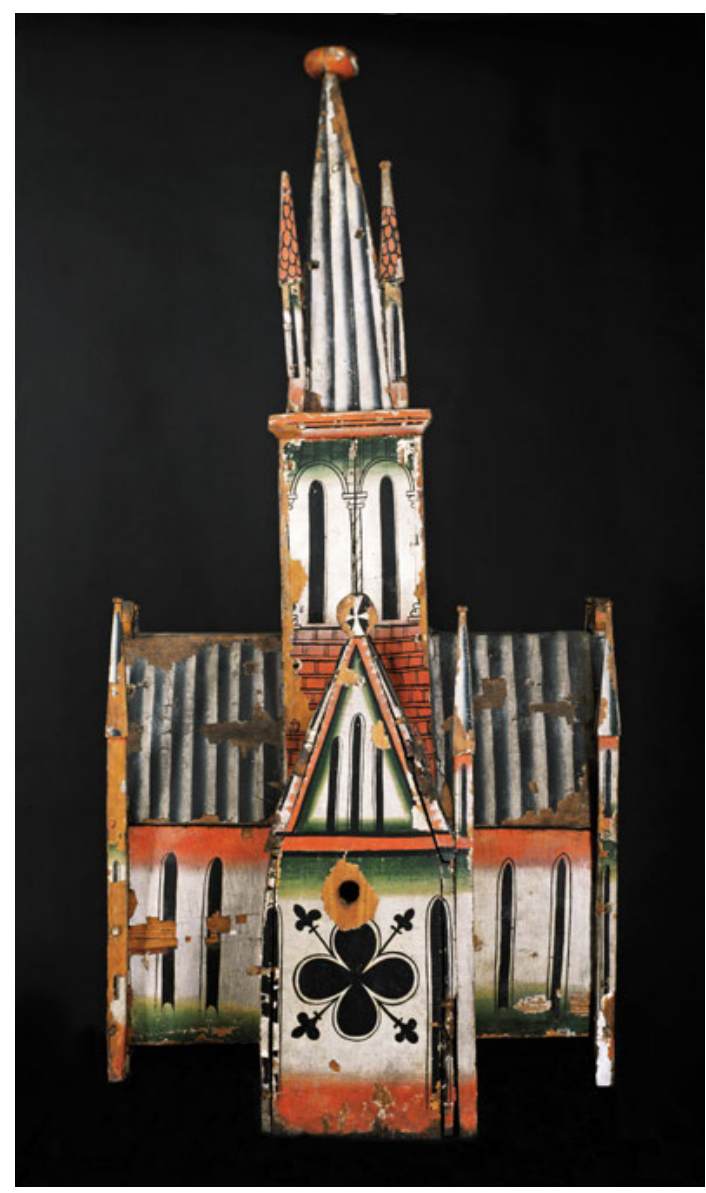

Fig. 20.6: Wooden church model, probably the headpiece of a ciborium. Oslo University Museum of Cultural history. and historiography of various

kinds. Furthermore, they include lists of holy places, itineraries, and descriptions of the earthly paradise. Most of these texts were either composed or translated and adapted to Old Norse during the second half of the twelfth century, and have come down to us through a group of nine fourteenth-century manuscripts or manuscript fragments. ${ }^{10}$ In the texts translated from Latin, we find several interpolations with

10 Rudolf Simek, Altnordische Kosmographie: Studien und Quellen zu Weltbild und Weltbescheibung in Norwegen und Island vom 12. bis zum 14. Jarhhundert, Ergänzungsbände zum Reallexikon der Germanischen Altertumskunde 4 (Berlin - New York: de Gruyter, 1990): 370-71. 
supplementary information on things related to the northern world and comments regarding linguistic differences between Latin and Old Norse. ${ }^{11}$

Rudolf Simek has studied the cosmological and geographical content in this text cluster and taken an interest in the Jerusalem maps as geographical documents. As he concentrates exclusively on cosmography and geography, he has omitted from his study the other text genres belonging to the cluster and to the codicological proximity of the Jerusalem maps. According to Simek's categorization, cosmological and geographical information occurs in three categories of Old Norse manuscripts: 1) "Enzyklopädische Handschriften, welche die meisten kosmographischen, geographischen und etnographischen Texte enthalten;" 2) "Astronomischkomputistische Sammelhandschriften;" and 3) "Handschriften eigenständiger Werke, welche Stellen kosmographischer Natur enthalten."12 The manuscripts containing Jerusalem maps belong to Simek's category 1 and 2. One may question, of course, whether it is relevant to categorize medieval texts according to these modern academic disciplines. In his monograph on Icelandic cartography, Dale Kedwards gives a timely reminder that what we today classify as geographic and cosmographic knowledge, medieval authors tended to categorize as geometry. ${ }^{13}$ As one of the seven liberal arts, geometry traditionally embraced information about the size and shape of the world, and of the properties of peoples. For the investigation of the Icelandic Jerusalem maps with their eminently geometric rendering of the city, this premodern categorization of knowledge will prove to be relevant, as I hope to show. In the following, I shall thus give a brief description of the codicological environs of the three Icelandic Jerusalem maps.

\section{AM 732b 4to (c.1300-1325)}

This manuscript is a fragmented bilingual encyclopaedia of nine folios (one quire plus a single leaf), written in two hands. ${ }^{14}$ The preserved folios contain texts on computus (calendar calculation), measures, cosmography, and astronomy, as well as mnemonic verses of different kinds. Geometric diagrams dominate the preserved pages. Preceding the circular Jerusalem map on fol. 8v (Fig. 20.1), there are six more circular designs scattered about the nine folios: a wind diagram; a hemispherical world map; a concentric diagram listing the elements, the planets, and the celestial spheres; a zodiac diagram; a circular labyrinth; and an (incomplete?)

11 This practice is referred to as "autopsy" in philological scholarship; see Dale Kedwards, "Cartography and Culture in Medieval Iceland" (PhD Thesis, University of York, 2014), 69.

12 Simek, Altnordische Kosmographie, 368-69.

13 Kedwards, "Cartography and Culture in Medieval Iceland," 17.

14 Kedwards, “Cartography and Culture in Medieval Iceland,” 87. 


\begin{tabular}{|c|c|}
\hline $\begin{array}{l}\text { Folio/ } \\
\text { quire }\end{array}$ & AM 732b 4to \\
\hline $1 \mathrm{r}$ & Text on how the conjunctions of the sun and moon produce the tides. Reference to Bede. \\
\hline $1 v$ & Notices on calendar computing. Latin mnemonic verses. \\
\hline $2 r-v$ & Diagram of winds. Latin text from Isidore on the same. \\
\hline $2 v-3 r$ & Old Norse text on the lunar cycle. Hemispherical world map. \\
\hline $3 v-4 v$ & $\begin{array}{l}\text { Diagram of the planetary spheres and the four elements. Old Norse text on the length } \\
\text { of days and the course of the sun. }\end{array}$ \\
\hline $4 v-5 v$ & Exercises for Latin grammar and syntax. \\
\hline $6 r$ & $\begin{array}{l}\text { Macrobius dicens. Old Norse text referring to Macrobius on the constellations and the } \\
\text { movements of the planets. Zodiac diagram. }\end{array}$ \\
\hline $6 \mathrm{v}$ & $\begin{array}{l}\text { Latin text referring to St Jerome about fifteen signs appearing before the Last days. List } \\
\text { of the names of the Hebrew letters and their (allegorical) meaning. Notice on the } \\
\text { importance of keeping the canonical hours. }\end{array}$ \\
\hline $7 r$ & $\begin{array}{l}\text { Short notice on the martyrdom of St Kilian and his followers. Labyrinth with the } \\
\text { inscription Volunðar hús. Measure of Christ's body with a comment both in Norse and } \\
\text { Latin. List of the five bonae cogitationes, seven steps of wisdom, and an explanation on } \\
\text { how thoughts, words, and deeds may lead man to heaven or to hell. }\end{array}$ \\
\hline $7 v$ & $\begin{array}{l}\text { Diagram of the lunar and solar cycles, four lesser circles for the calculation of calendæ, } \\
\text { nonæ and idus during the twelve months of the Julian calendar. Scheme of the } \\
\text { fundamental attributes of God, soul, and body. }\end{array}$ \\
\hline $8 r$ & $\begin{array}{l}\text { Latin explanation of a computus manualis for remembering the signs of the zodiac and } \\
\text { the names and characteristics of the planets. Figure of hand. Short notice on the Late } \\
\text { antique historian Orosius (frásagnamaðr). }\end{array}$ \\
\hline
\end{tabular}

8v Map of Jerusalem with Latin legends. Notice on measures and calculations of weights and currencies and two verses in Old Norse.

9r-v Text on zodiac signs and planets' names and their origins in classical mythology, with a reference to Ovid. Arab numbers, Latin alphabet.

figure illustrating the lunar circle during the year. In addition, the figure of a human hand functions as a mnemonic device for calculus rules. Framing these diagrams are several short texts, some in Latin and some in the vernacular, elaborating on the information found in the diagrams. Some of the texts have, however, no apparent connection with the figures. An overview of the compiled texts and figures and their distribution across the nine folios follows below.

From the overview above, we may establish that a recurrent theme in what remains of this encyclopaedic manuscript is the movement of the celestial bodies. Another theme related to this one is the issue of calculation and measurement, particularly the measure of time, but also of weights, currencies (fol. 8v), and the 
length of Christ's body (fol. 7r). In some of the texts an eschatological dimension is clearly pronounced.

\section{AM 736 I 4to (c.1300-1350)}

This is a manuscript fragment of two folios, seemingly originating from a similar encyclopaedic compilation as AM 732b 4to. Two hands have been identified: one is responsible for fols $1 \mathrm{r}-2 \mathrm{r}$ and dated to ca 1300, whereas the second is responsible for fol. $2 \mathrm{v}$ and dated to ca $1350 .{ }^{15}$ In addition to the full-page map of Jerusalem on $2 \mathrm{r}$ (Fig. 20.2), there are two cosmographic diagrams, both of them corresponding to two of the diagrams in AM 732b 4to. It emerges that this encyclopaedic manuscript fragment contains the same kind of and calendar-related texts and diagrams as in AM 732b 4to. In addition, geographical and topographical description seems to be the main interest here.

\begin{tabular}{|c|c|}
\hline $\begin{array}{l}\text { Folio/ } \\
\text { quire }\end{array}$ & AM 736 I 4to \\
\hline $1 \mathrm{r}$ & $\begin{array}{l}\text { Sva er kallat sem prideild se iord: Old Norse text describing the three continents of the } \\
\text { world; sometimes referred to as "the Icelandic Geographical Treatise". }{ }^{16} \\
\text { Gaspar balthasar melchior: Unreadable text headed with the names of the biblical magi }\end{array}$ \\
\hline $1 v$ & $\begin{array}{l}\text { Galterus meistari segir solar gang: Note in Old Norse on the error in the Julian } \\
\text { calendar. Hemispherical world map. Old Norse text on the lunar cycle and the tides. } \\
\text { Rota diagram of the planetary spheres and the four elements. Latin verse on the cross. }\end{array}$ \\
\hline $2 r$ & Map of Jerusalem (Jorsalaborg) with Latin legends. \\
\hline $2 v$ & Description of Jerusalem and the Church of the Holy Sepulchre in Old Norse. \\
\hline
\end{tabular}

\section{AM 544 4to (Hauksbók, c.1300-1350)}

The most famous of the Icelandic manuscripts containing Jerusalem maps is the so-called Hauksbók, a huge, composite compilation with a complex transmission history. This text corpus is traditionally connected to the learned Icelandic magistrate [lagmann] Haukr Erlendsson, a member of the Norwegian elite, who died in

15 Kedwards, "Cartography and Culture in Medieval Iceland,” 67.

16 Simek refers to this text as "Kurze Weltbeschreibung”, Simek 1990, Altnordische Kosmographie, 428. 
Norway in $1334 .{ }^{17}$ The main compilation is dated $1300-1310$, and has subsequent fourteenth-century additions. At some point it was split into three separate quarto manuscripts, of which the one containing the Jerusalem map, AM 544 4to, is the largest. $^{18}$

The map of Civitas Hierusalem famosissima is found on fol. 19r of AM 544 4to, in the middle of the third quire (Fig. 20.3), and it is the only proper illustration or diagram in the entire manuscript - at least in its extant form. The parchment is cut across the page, so that the lower part is missing, which, of course, makes it difficult to determine the map's original immediate context. It is preceded by a collection of texts with geographical and theological content (fols 1r-18v), and followed by a brief text on excommunication (fol. 19v) as well as the mythological Old Norse poem Voluspá (fols 20r-21r). Due to a lacuna between quire 2 and 3, Finnur Jónsson considered the texts preceding the Jerusalem map to be two separate entities, and in his edition of Hauksbók, they were given the titles Heimslýsing ok helgifræði (quires 1 and 2; fols 1r-14v) and Heimspeki ok helgifræði (first part of quire 3, fols $15 \mathrm{r}-19 \mathrm{v}) .{ }^{19}$ From a codicological point of view, there is reason to consider them as two "production unities" which may have existed as two separate booklets before they were added to Hauksbók sometime after Haukr Erlendsson's death in $1334 .^{20}$ The main body of texts in these three quires (fols $1 \mathrm{r}-18 \mathrm{v}$ ) is attributed to two Norwegian scribes and dated to ca 1300 , whereas the remainder of the third quire (fols 19r-21v), including the Jerusalem map and the Eddic poem Voluspá, seem to have Icelandic origin and date from the first generation after Haukr's death. Karl G. Johanson suggests that the scribes responsible for these late additions were

17 It has generally been assumed that most of the compilation was written or at least commissioned by Haukr himself, whereas recent scholarship tends to question the character of Haukr's connection to the book, and argues that the extant manuscript represents "various stages of production," cf. Karl G. Johansson, “The Hauksbók: An Example of Medieval Modes of Collecting and Compilation," in The Dynamics of the Medieval Manuscript, ed. Karen Pratt, et al. (Göttingen: V\&R Unipress, 2017).

18 The two others, also in the Arnamagnæan Collection, have shelf marks of AM 3714 to (presently kept in Reykjavik) and AM 675 4to (presently kept in Copenhagen). A complete edition of Hauksbók appeared in Copenhagen in the 1890s, see Hauksbók. Udgivet efter de Arnamagnæanske håndskrifter no. 371, 544 og 675, 40, samt forskellige papirshåndskrifter af Det Kongelige Nordiske Oldskrift-Selskab, ed. Finnur Jónsson (Copenhagen: Thieles Bogtrykkeri, 1892-1896).

19 These labels, which may be translated as "Description of the world and knowledge of the sacred" and "Wisdom of the world and knowledge of the sacred" respectively, do not occur in the manuscript and seem to be the editor Finnur Jónsson's invention. At the beginning of the eighteenth century, Arni Magnusson described the two first quires as "geographica quaedam et physica, theologica quaedam ex sermonibus Augustini, Varia, atque inter ea Astronomica quaedam." The third quire he characterized as "theologica quaedam videtur esse ur Adamsbók," cf. Katalog over Den arnamagnæanske håndskriftsamling udgivet af Kommisionen for det arnamagnæanske legat, 2 vols (Copenhagen 1889-1894).

20 Johansson, “The Hauksbók,” 137-38. 
associated with the Benedictine monastery pingeyrar in Northern Iceland. ${ }^{21}$ As the following analysis shows, a monastic setting is reasonable for this and the two other manuscripts containing Jerusalem maps.

Although the first three quires presumedly existed as two separate booklets written by two different Norwegian scribes, they were at some point, probably in an Icelandic monastery about 1350, conceived of as one unit, perhaps independently of the rest of AM 544 4to. Hence, I will consider them as one thematic entity in the following. ${ }^{22}$ The compiled texts, all of them in Old Norse and enumerated consecutively for the purpose of this analysis, are as follows:

\begin{tabular}{|c|c|c|}
\hline $\begin{array}{l}\text { Folio/ } \\
\text { quire }\end{array}$ & $\#$ & AM 544 (Hauksbók) \\
\hline \multicolumn{3}{|l|}{ Quire 1} \\
\hline $1 r-v$ & 1 & On the waters of the world, originating from the four rivers of Paradise. \\
\hline $1 \mathrm{v}$ & 2 & $\begin{array}{l}\text { Prologus; referring to a biblical (Moses) as well as a classical (Herodotus) authority } \\
\text { for the legitimation of history writing. }\end{array}$ \\
\hline $2 r$ & 3 & Fra paradiso. A description of the earthly Paradise and the Tree of Life. \\
\hline $2 r-4 r$ & 4 & $\begin{array}{l}\text { Her segir fra pui hversu lond liggia i veroldenni. A description of the world and its } \\
\text { three continents. }\end{array}$ \\
\hline $4 r-8 r$ & 5 & $\begin{array}{l}V m \text { pat hvaðan otru hofst. (Homiletic?) text on false religion and the necessity of } \\
\text { monotheism. }\end{array}$ \\
\hline $8 r-v$ & 6 & $\begin{array}{l}\text { Fra puí huar huerr Noa sona bygði heiminn. On the sons of Noah who populated the } \\
\text { world and spread to all lands. }\end{array}$ \\
\hline $8 v$ & 7 & $\begin{array}{l}\text { Her segir fra marghattaðum pioðum: Description of the "monstrous races" living at } \\
\text { the edge of the world. }\end{array}$ \\
\hline Quire 2 & & Continued: \\
\hline $9 r$ & & Her segir fra marghattaðum pioðum. \\
\hline $9 r-10 v$ & 8 & Her segir. . . : On heretics and false prophets, referring to Augustine. \\
\hline
\end{tabular}

21 Johansson, "Om nordisk och lärt hos de tidiga benediktinarna på Island," and Johansson, "The Hauksbók," 132.

22 Here, I deviate methodologically from Karl G. Johansson, who has authored the most recent study of this manuscript and analyzed its codicology. Johansson upholds Finnur Jónsson's distinction between quire 1 and 2 on the one hand and quire 3 on the other, which is sound from a codicological point of view. There are, however, textual and thematic links between the two and the Jerusalem map, as I will subsequently show. My emphasis is thus the conceptual and rhetorical unity between the texts in the three quires, which must have been evident when the two entities were bound together, and which is clearly enhanced by the insertion of the Jerusalem map about 1350. 
(continued)

\begin{tabular}{|c|c|c|}
\hline $\begin{array}{l}\text { Folio/ } \\
\text { quire }\end{array}$ & \# & AM 544 (Hauksbók) \\
\hline $10 v-11 r$ & 9 & $\begin{array}{l}\text { Her segir hvaðan blot skur guða hofust: Dialogue between a student (Discipulus) } \\
\text { and his teacher (Magister), discussing idolatry and the reasons for its existence. }\end{array}$ \\
\hline $11 \mathrm{r}$ & 10 & Her segir fra draumum: Dialogue form continued. On the origin of dreams. \\
\hline $11 \mathrm{r}-\mathrm{v}$ & 11 & Her segir fra Antíchristo: Dialogue form continued. On the prophecy of Antichrist. \\
\hline $12 r$ & 12 & $\begin{array}{l}\text { Vm uprisu kuicra oc dauða: Dialogue form continued. On the resurrection of the } \\
\text { flesh at the end of time. }\end{array}$ \\
\hline $12 r-13 r$ & 13 & $\begin{array}{l}\text { Vm íbru daga hald: On fasting on the so-called ember days (imbrudagar) and their } \\
\text { biblical (Mosaic) legitimation. }\end{array}$ \\
\hline $13 r-v$ & 14 & $\begin{array}{l}V m \text { regnboga: Description of the rainbow with an explanation of its allegorical } \\
\text { significance. }\end{array}$ \\
\hline $13 v-14 r$ & 15 & Vm solstoðr: On the calendar and the solstices. \\
\hline $14 \mathrm{r}-\mathrm{v}$ & 16 & $\begin{array}{l}\text { Vm borga skipan oc legstaðe heilgara manna: List of towns with important relics } \\
\text { and the burial places of notable saints. }\end{array}$ \\
\hline \multicolumn{3}{|c|}{ Lacuna (2 folios) } \\
\hline
\end{tabular}

Quire 3

\begin{tabular}{lrl}
$15 \mathrm{r}$ & 17 & Fragment, ending a narrative about a servant of God. \\
\hline $15 \mathrm{r}-16 \mathrm{r}$ & $18 \begin{array}{l}\text { Fra heilræðum spekinga: Dialogue between a student (lærisveinn) and his teacher } \\
\text { (Meistari) on the brevity of life and the importance of remembering death. }\end{array}$ \\
\hline $16 \mathrm{r}-17 \mathrm{r}$ & $\begin{array}{r}19 \\
\text { Af natturu mannzins ok bloði: On the correspondence between the four humours } \\
\text { and the four elements. }\end{array}$ \\
\hline $17 \mathrm{r}-18 \mathrm{v}$ & 20 Huaðan kommin er + drottins: The legend of the Wood of the Holy Cross. \\
\hline $18 \mathrm{v}$ & 21 Pesser eru xíj heíms osomar: On twelve unseemly things leading to damnation. \\
\hline $19 \mathrm{r}$ & 22 Map of Jerusalem with Latin legends. \\
\hline $19 \mathrm{v}$ & 23 On the conditions of excommunication. \\
\hline $20 \mathrm{r}-21 \mathrm{r}$ & 24 Voluspá.
\end{tabular}

As we see from the above, the three first quires of AM544 4to make up a miscellaneous corpus of texts, drawn from a variety of sources. ${ }^{23}$ Notwithstanding the

23 The four pieces in dialogue form (texts 9-12) seems to be based on Honorius Augustodunensis' Elucidarius, whereas texts 3-8, 13-16, 19, 21, and 22 (the Jerusalem map) correspond to similar texts in the Liber Floridus, a compendium of theology, cosmology, nature lore and historiography 
disparity of this compilation, a few themes repeatedly recur. Some we have already met in the surroundings of the other two Jerusalem maps: these are issues related to the calendar, the movements of the celestial bodies and the relation between man and cosmos (nos 13, 14, 15, 19), and issues related to world description and significant places (nos 1, 3, 6, 7, 16, 22). In addition, there are texts that may be characterized as historiography in the widest sense (nos 2, 20, 24). Furthermore, several of the texts relate to the discrimination between true and false religion and the conditions of salvation (nos 5, 8, 9, 10, 11, 21, 23). Neither of these thematic categories is exclusive, and dimensions of all themes are found in most of the texts. Moreover, all of them without exception are informed by and /or refer to the master narrative underlying medieval encyclopaedic literature in general: that of the history of salvation. ${ }^{24}$ Within this conceptual and thematic entity composed of the first three quires of AM 544 4to, the geometric rendering of Jerusalem at fol. 19r plays a certain role as a structuring device - as do, I argue, the Jerusalem maps in the two fragmented encyclopaedias AM 732 I 4to and AM 736I 4to. In the following, I shall therefore treat the three maps and their surrounding texts in parallel - although greatest emphasis is placed on the first three quires of AM 544 4to (Hauksbók) with its richer selection of texts.

\section{Recurrent Themes in the Texts Surrounding the Three Icelandic Jerusalem Maps}

Taken as a whole, the textual surroundings of the Jerusalem maps in all three manuscripts display striking thematic similarities. The concern about celestial bodies and the measuring of time is already mentioned, as is the interest in geographical description and what we could call sanctified topography, pointing out holy places as "centres of immanence." 25 Both themes may be seen as symptoms of the need to assure the northern lands a place within the realm of Christendom, both in time and space. Preoccupation with the measurement of time and the urge to overcome the deficiencies of the Julian calendar were imperative issues for the whole of

compiled by Lambert, a canon of Saint-Omer in Artois near the border of today's Belgium. However, the correspondences with Liber Floridus are by no means direct translations; cf. Simek, Altnordische Kosmographie, 381-83.

24 Mary Franklin-Brown, Reading the World. Encyclopedic Writing in the Scholastic Age (Chicago: University of Chicago Press, 2012). Cf. the introduction to this volume, Chapter 1 (Kristin B. Aavitsland), 22-4.

25 Hans Henrik Lohfert Jørgensen, "Sensorium: A Model for Medieval Perception," in The Saturated Sensorium: Principles of Perception and Mediation in the Middle Ages, ed. Hans Henrik Lohfert Jørgensen, et al. (Aarhus: Aarhus University Press, 2015), 29. 
the Christian oikumene, and proper calculation of time was required in order to celebrate Easter at the right time, along with the rest of the Church. ${ }^{26}$ The recurrent descriptions of the inhabited world testify to a similar need to be included in Christendom. All three manuscripts hint several times that the sons of Noah are "builders" of each part of the inhabitable world and thus ancestors to the three continents. This is a commonplace in medieval encyclopaedic knowledge, verbally suggesting the figure of the T-O map. Text no. 6 of AM 544 4to (Hauksbók) is no exception to this rule: "Sem got that part which is called Asia and makes up the half of the world. And Japhet son of Noah was to build the northern part of the world, which is called Europe. And Kam, the third of Noah's sons, was to build the land which is called Africa."27 However, the author adds geographic details of the north to the commonplace description of how Noah's son Japhet populated Europe, carefully mentioning Sweden, Denmark, and Norway [Svipioð oc Danmore oc Noregi]. A similar feature is also found in the fragmented encyclopedia AM 736 I 4to: Geographical description derived from authorities like Isidore, Martinanus Capella, and Eusbeius is supplemented with details about Iceland and the North Atlantic that were unknown to the acknowledged auctores. ${ }^{28}$ In these texts, the Icelandic authors explicitly inscribe the northern territories to authoritative accounts of the inhabited world.

Another interesting feature is the remarkable emphasis on mission and the spread of Christianity in some of the geographical texts. The geographical treatise in AM 736 I 4to (fol. 1r) describes the three continents of the world, including biblically significant places like Babylon and Jerusalem. Here, painstaking care is taken to mention who converted the lands described. Moreover, reflections about the pagan past of the ancient Mediterranean world as well as the countries in the north occur in several of the texts. Related to this theme are the frequent mentions of Babylon as the cradle of polytheism and idolatry. The linguistic chaos of Babel, described in Gen 11: $1-9$, is interpreted as an analogy to the religious chaos of multiple faiths. In texts no. 5 and no. 9 in AM 544 4to (Hauksbók), for instance, heathendom and pagan practices are associated with the sinful state of man before the flood. In these texts, which are seemingly adapted from Lambert of St. Omer's Liber floridus and Honorius Augustodunensis' Elucidarius respectively, the story of Babel is understood mainly as the paradigm of idolatry: the confusion of languages leads to the confusion of mind and difficulties in recognizing the creator and true God. Instead, a plurality of faiths and cults parallels the plurality of languages. The ancient pantheon is described as men and women made gods by the heathens, hence the error of idolatry inflicts the

26 Kedwards, “Cartography and Culture in Medieval Iceland,” 79.

27 "Sem hafðe pann lut heimsens er asia heítí. pat er kallat helmíngr heímsens. En Iafeth sonr Noa skilldi byggia norðr halfo heimsens, pat er kallat Europa. En Kam hinn priði Noa sonr. hann skilldi byggia pat land er Africa heitir,” Hauksbók, 165/310.

28 Kedwards, "Cartography and Culture in Medieval Iceland," 69. 
landscape, producing barren wastelands. ${ }^{29}$ Predictably juxtaposed with descriptions of this barrenness is the lushness of the converted lands, and the paradisiac topos of the lush and sprouting tree combined with running water - a common symbolic reference to baptism - frequently occurs.

Yet a theme surfacing frequently is that of the hidden knowledge of Christ in pre-incarnation history. Not only the Old Testament, but also other historical narratives are understood as imbued with typological information of Christ, as I will show further below. Eschatology is another leitmotiv in the texts surrounding the Jerusalem maps, often connected to the apocalyptic prophesy of the Antichrist. ${ }^{30}$ The figure of the Antichrist will rise from Babylon and is hence connected both to idolatry and whoredom. He will conquer the world by cunning and terror, but all his performances are false and his signs are lies [oll tacn hans ero lygin]. Jerusalem plays a prominent role in this narrative: the Antichrist installs himself there as if he were God, allies with the Jews, and will eventually be defeated at the Mount of Olives [i fiallenu Oliueti] after seven years of reign. ${ }^{31}$

Thus, we may conclude that the texts compiled in the manuscripts with Jerusalem maps share a common urge to interpret the physical world, the past, and the future in light of the master narrative of salvation history, and to claim the universal and eternal truth of the Christian faith despite the historical existence of other beliefs. Against this background, I shall investigate the ways in which the circular Jerusalem maps may add significance to these concerns.

\section{Cognitive Geometry: The Quadripartite Circle}

As emphasized above, the constituting feature of the three Icelandic Jerusalem maps is the cruciform city plan inscribed by a circular wall (Figs. 20.1-20.3). This cross within an orb is a figure with symbolic meaning in its own right: it hints at the universal realm of Christ. Moreover, the geometrical design has further potential for generating meaning - the cross and the orb make up a quadripartite circle, which is one of the most common diagrammatic schemes in medieval "encyclopaedic" literature. Lambert's Liber floridus, for example, abounds with such quadripartite diagrams, and they occur frequently in manuscript illumination from the twelfth through the

\footnotetext{
29 Hauksbók, 157-58 and 70.

30 AM 544 4to (Hauksbók 1892-1896), text nos 9, 11.

31 The preoccupation with the Antichrist may associate to a feature in narratives of the Holy Land from the thirteenth and fourteenth centuries, especially in Franciscan exegesis, in which the Antichrist is associated with Mohammad, cf. Marianne Ritsema van Eck, "Custodians of Sacred Space. Constructing the Franciscan Holy Land through Texts and sacri monti (ca. 1480-1650)" (Doctoral dissertation, Amsterdam University, 2017), 122.
} 
fourteenth centuries, as well as in monumental art. ${ }^{32}$ The quadripartite circle is a figure suitable for visualizing a concept that was central to the medieval paradigm of knowledge: that of analogies in the created universe, like the correspondences between the four seasons, the four elements, and the four humours of the human body. Hence, it is a prominent example of what Mary Carruthers recently has characterized as cognitive geometries: "the medieval creative practice among geometric shapes, meditation, and the human ability to create original works." 33 Carruthers claims that cognition and topical invention happened by the use of geometric diagrams in the minds of the intellectually trained during the High Middle Ages. This claim finds support in influential, widely distributed and much-quoted medieval authors like, for instance, Hugh of St. Victor. ${ }^{34}$ If we take this as a condition also valid for the scribes behind the Icelandic manuscripts under discussion here - and there is little reason not to - it is interesting to observe how the scheme of the quadripartite circle is found, not visually, but verbally, in some of the texts surrounding the Jerusalem map in Hauksbók. Two of these are text no. 13, Vm ímbru daga hald, and text no. 19, Af natturu mannzins ok bloði, which both have parallels in Lambert of St. Omer's Liber floridus.

Text no. 13 explains the practice and meaning of the so-called ember days. These are yearly fast days at the beginning of each quarter of the year, which should be kept, as in the times of Moses, the text argues, for agricultural benefit. Hence, these fast days are clearly connected to the seasons and the cycle of the year. The allegorical meaning (or mnemonic pedagogy?) of their number (3x4) is explained, according to theology (trinity; gospels; apostles) and knowledge of nature (three parts of mind/ spirit; four elements and four humours making up the body). Hence, entities that may be visualized by a circle (the cosmos, the year, the human life-span, God's revelation) and entities that come in fours (elements, humours, seasons, gospels) are integrated in the text as a kind of mental diagram of a quartipartite circle - or a circle spanning the figure of the cross. By fasting on the ember days at each quarter of the year, this diagram is embodied and performed: conceptually, the ember days make up a cruciform pattern across the cycle of the year.

In text no. 19 a similar mental diagram is created. The text explains how the four elements existed from creation, and how they are distributed and exchanged across the cosmos. Furthermore, it describes how this distribution has a correspondence in

32 A well-known example on a monumental scale is the microcosmos-macrocosmos diagram in the frescoed crypt of the cathedral of Anagni, dated 1225-1250.

33 Carruthers, "Cognitive Geometries."

34 Hugh, whose didactic book on the arts was paramount for the intellectual culture of the High Middle Ages, refers to geometry as "fons sensuum et origo dictionum," that geometry is "the wellspring of our sensory cognition and the source of the things we say," Hugh of St. Victor, Didascalicon, PL, 176. See also Kristin B. Aavitsland, Imagining the Human Condition in Medieval Rome. The Cistercian Fresco Cycle at Abbazia delle Tre Fontane (Aldershot: Ashgate, 2012), 203. 
man (Adam created from the red earth of Hebron), as the four temperaments correspond with the four elements and their properties (cold/warm; dry/humid); and the changes in temper follow the changing seasons during the year and in the course of man's life. The correspondence between world and man, macrocosmos and microcosmos, is one of the most frequent uses of the quadripartite circle diagram in medieval culture. This well-known commonplace, more frequently communicated by visual means, is given a verbal form in text no. 19.

The world described in these and most other texts of the first three quires of AM 544 4to, in AM 732 4to, and AM 736 I 4to has Jerusalem as its geographical as well as moral centre. Jerusalem is the spot on earth where the transcendent had proved to break through [axis mundi]. Hence, its design may be considered a key to knowledge of this divinely created world. Within the paradigm of medieval learning, the city plan of Jerusalem is a figure of cognitive geometry with pedagogic as well as mystical qualities.

\section{The Holy Cross: Cosmic Sign and Wooden Substance}

In the three Icelandic Jerusalem maps, the cruciform city plan is pronounced more explicitly than in the twelfth-century ones, as we saw above. Interestingly, the figure of the cross is also a recurrent motif in the manuscript environments of all three Jerusalem maps under discussion here. Cruciform figures occur not only indirectly through textual references to the diagrammatic qualities of the quadripartite circle, as we saw above, but also as explicit mentions of the cross of Christ, in which the form of the cross as well as its physical substance play significant argumentative roles. Some examples follow.

Text no. 8 in AM 544 4to (Her segir . .., fols 9r-10v) warns against false prophets, heathen rites, and witchcraft. ${ }^{35}$ Towards the end of the text, the sign of the cross [guðs pinslar marke] is introduced as more powerful than heathen practices and as the most efficient means against the snares of the devil. Making the sign of the cross aids memory to contemplate the wood on which the Lord suffered [lata oss pann cross pa i hug koma er drottenn vár var píndr a]. Moreover, the cross is embedded with great significance [miklar iartegnir]. The universal significance of God's sacrifice is indicated in its form: lying on the ground, the cross becomes a figure of the world, pointing to (showing towards?) all four directions [ef crossenn er lagðr niðr a iorð pa synir hann sic yfir iiij halfor heimsens, austr oc vestr, norðr oc suðr], while standing upright it connects heaven and earth [ $p$ a tacnar hann beði hifneska luti oc iarðne$s k a$. This didactic reading of the figure of the cross is originally drawn from a sermon

35 Hauksbók, 167-70. 
by Augustine, and is referred to by numerous medieval authors. ${ }^{36}$ The widely distributed Legenda aurea, compiled ca 1260, quotes Augustine's sermon in a wording that seems quite close to the Hauksbók text. On Norse ground, similar interpretations of the cross are found both in the Old Norse Homily Book (May 3, Inventio crucis) and in the Old Icelandic homily book. ${ }^{37}$ In AM 544 4to, the interpretation of the cross's design as an image of the world inevitably mirrors the orbicular and cruciform Jerusalem map, which in the present binding is placed eight folios away.

The three manuscripts containing Jerusalem maps refer to the Holy Cross not only as sign and geometrical figure, but also as material substance. Since St Helena's assumed discovery of the true cross in Jerusalem in the fourth century, its wood had been the most precious and prestigious relic in Christianity, surrounded by political significance, but also by poetic, legendary, and didactic discourse. The three Icelandic manuscripts contain several traces of these centuries-old traditions, most prominently in AM 544 4to (Hauksbók), in which fols 17r-18v are reserved for the legend of the Wood of the Cross (text no. 20).

Several texts about the Wood of the Cross and its typological significance appeared in historiographic works by twelfth-century authors like Honorius Augstodunensis, Petrus Comestor, Godfrey of Viterbo, and Lambert of St. Omer. ${ }^{38}$ Obviously fuelled by typological enthusiasm, these texts aim to trace the predictions of the cross of Christ in the stories from the Old Testament; and hence a number of legendary motifs, sometimes mutually contradictory, were generated. ${ }^{39}$ Around 1200, a group of narratives emerged in monastic environments, drawing on this theologicalhistoriographical tradition as well as on the rich apocryphal literature connected to Adam and Eve. These narratives share a general storyline relating the history of the Wood of the Cross from the last days of Adam until the last days of Christ, construed as the New Adam. At the core of this group of texts is a Latin prose version from ca 1220, simply called the Legenda. It was translated into several vernaculars (Old French, Middle English, Flemish), and it seems that it is also the basis for the Old

36 Augustine of Hippo, Sermo 53, PL, 38. The fifth-century author Sedulius, much quoted throughout the Middle Ages, presents a similar reflection, as does Honorius Augustodunensis. Both of them informed Old Norse devotional literature extensively.

37 In the homily for the feast of Inventio crucis, the Old Norse Homily Book adds an explanation of the site of the crucifixion (my translation): "Thus our Lord suffered in the middle of the world, where the distance to all ends of the world is the same, so that the mercy we receive through his suffering is as near for all those who adore him in faith and through good works" (Af pvi var droten i miðium hæimi pindr par er iam-langt er til allra hæims ende, at iam-nær er ollum miscun pinslar hans peim er hann gofga með tru ok goðum vercum), Gamal norsk homilebok: Cod. AM. $6194^{\circ}$, ed. Gustav Indrebø (Oslo: Kjeldeskriftfondet, 1966).

38 Barbara Baert, A Heritage of Holy Wood: The Legend of the True Cross in Text and Image, Beliefs, and Traditions (Leiden: Brill, 2004), 291-4.

39 Baert, A Heritage of Holy Wood gives a thorough account of the cluster of legends surrounding the True Cross and their diffusions in texts and images throughout the medieval period. 
Norse legend of the cross in AM 544 4to. ${ }^{40}$ The story may be summarized as follows: Adam repented his sin, and God promised him that by the end of the world [við enda heimsins] he would receive the oil of mercy [miskunnar oleum]. As he approached death, Adam sent his son Seth to follow his parents' footprints back to Paradise to fetch the oil for him. Seth reached Paradise, marvelled at its wonderful brilliance and presented his errand to the guarding angel. He was then given visionary insight, as he saw the fountain from which the four rivers sprang that watered the entire world, and above it a huge tree [ifir kelldunni sá hann apalldr einn standa med morgum greinum]. A serpent was twining around its trunk [orm einn skreið umhverfs apalldrinn]. The tree was so large that its branches seemed to reach the sky and its roots went all the way down to hell. At the top, Seth saw a crying baby wrapped in swaddling clothes [barn eitt grátanda ok sveipt $i$ klæðum], whereas below, entangled in the roots, he recognized his brother Abel. The angel explained to him that the boy child is the Son of God, and that he is the oil of mercy promised to his parents [sveinbarn pat pu set er guðs sun . . . han er pat miskunnar oleum er peim var heitið]. Then Seth was given three seeds of the tree from which his father had eaten. The angel instructed him to plant them in his father's mouth when he had died, and explained that from the first, there will grow a cedar, from the second a cypress, and from the third a pine. In some versions of the legend, the pine is exchanged with the palm, yet another species of tree ripe with symbolic potential. These three different trees originating from the same fruit was, as the angel taught Seth, a representation of the Holy Trinity.

Seth then went back to his dying father and let him know that in the fullness of time [fullnaðr timans er kominn] his sin would be atoned for. Adam then rejoiced for the first time since he was banished from Paradise. Then everything occurred as the angel had foretold: Adam was buried in the valley of Hebron, and three blooming saplings [teinungar] grew from his mouth. The rods of Moses and Aaron were later taken from them, and these rods worked all the miracles [allar iartegnir] for the people of Israel in the desert on their way to the Promised Land. ${ }^{41}$ King Solomon had the tree cut when in need of building material for the temple in Jerusalem, but the wood from the wondrous tree behaved strangely, altered its size, and was impossible to fit into the structure. It was thus put down beside the sanctuary [ $b v i$ var pat lagt niðr hia mustarinu]. When the Queen of Sheba, the wisest of all heathen women [allra heiðanna kvenna vitruzt] came to Jerusalem, she recognized the significance of the rejected piece of wood, and foretold that one day a man will hang upon this

40 Baert, A Heritage of Holy Wood, 300. Baert, however, is not aware of the Old Norse version.

41 In AM 544 4to, Moses and Aaron's relation to the holy wood is mentioned only in a few lines. In the Latin Legenda, however, this part of the narrative is more elaborated, and a section is included about King David, who moves the three samplings to Jerusalem, experiences that they work miracles along the way, plants them in a well and observes that they grow into one single tree. As this part is omitted here, the passage from three different samplings into one single tree is more unclear than in other versions of the legends. 
wood whose death will cause the downfall of the Jews. Upon hearing this, King Solomon became anxious and submerged the wood into a great pond [i eitt stort fén]. In other versions of the legend, the pond is specified as Piscina Probatica or Pool of Bethesda, and the miraculous power of its salvific waters is elaborated upon. The wood lay hidden in the pond until it surfaced at the time of Christ, and his executioners used it as material for the cross. The legend in AM 544 4to concludes with the statement that the prophecy of the wise Queen proved to be true, as Emperor Titus sacked Jerusalem soon after the death and resurrection of Christ. Those of the Jews who survived his siege were sold cheaply as slaves. Since then, the Jews have been spread all over the world [um allan heim], deprived of land and power. The text thus ends in a clearly anti-Judaic key.

In this, as in most versions of the legend, the typological connection between the sin of Adam and the atonement of Christ is immediately established by the seeds growing from Adam's mouth, linking the Tree of Knowledge to the Wood of the Cross. Thus, the very substance of this miraculous wood becomes a material thread that can be traced across a number of sacred events, hinting at the deeper meaning of salvation history. Through the ages, the seeds from the lost paradise quietly and enigmatically grew into the new tree of life, the cross of Christ, which reopened paradise to fallen man. Moreover, the threefold Wood of the Cross exposes the Trinitarian nature of the true God to those who gain prophetic insight. One fundamental message communicated here is the Christian claim that the truth of Christ exists from the beginning of time, although hidden before the incarnation. This theme is in accordance with a dominating tendency running though most texts in the three first quires of AM 544, as we have seen above.

In the bifolio AM 736 I 4to we meet the mystical wood of the cross again. But here, the three types of wood have become four. On fol. 1v, facing the Jerusalem map at fol. $2 \mathrm{r}$, there is a Latin verse on the cross. The verse is written vertically from the bottom of the page, along a line framing the concentric diagram of the celestial spheres, which is one of two cosmological figures on this page (Fig. 20.7). ${ }^{42}$ The Latin verse reads:

In cruce pes cedrus stipes cipressus oliva fit tituli tabula brachia palma manu[s?] tenet

(In the cross, the foot is cedar, the trunk is cypress, the table of inscription is made from olive, and arms of the cross are palm, holding the hands).

The cedar and cypress we recognize from AM 544 and the legend of the Holy Wood, whereas the pine is here exchanged with the palm. These three woods make up the foot, the vertical and the horizontal beams of the cross. In addition, the wood of the inscription table that Pilate put above Christ's head is identified as olive.

42 Dale Kedwards overlooked this verse in his otherwise thorough discussion of AM 736 I 4to, cf. Kedwards, "Cartography and Culture in Medieval Iceland”. 


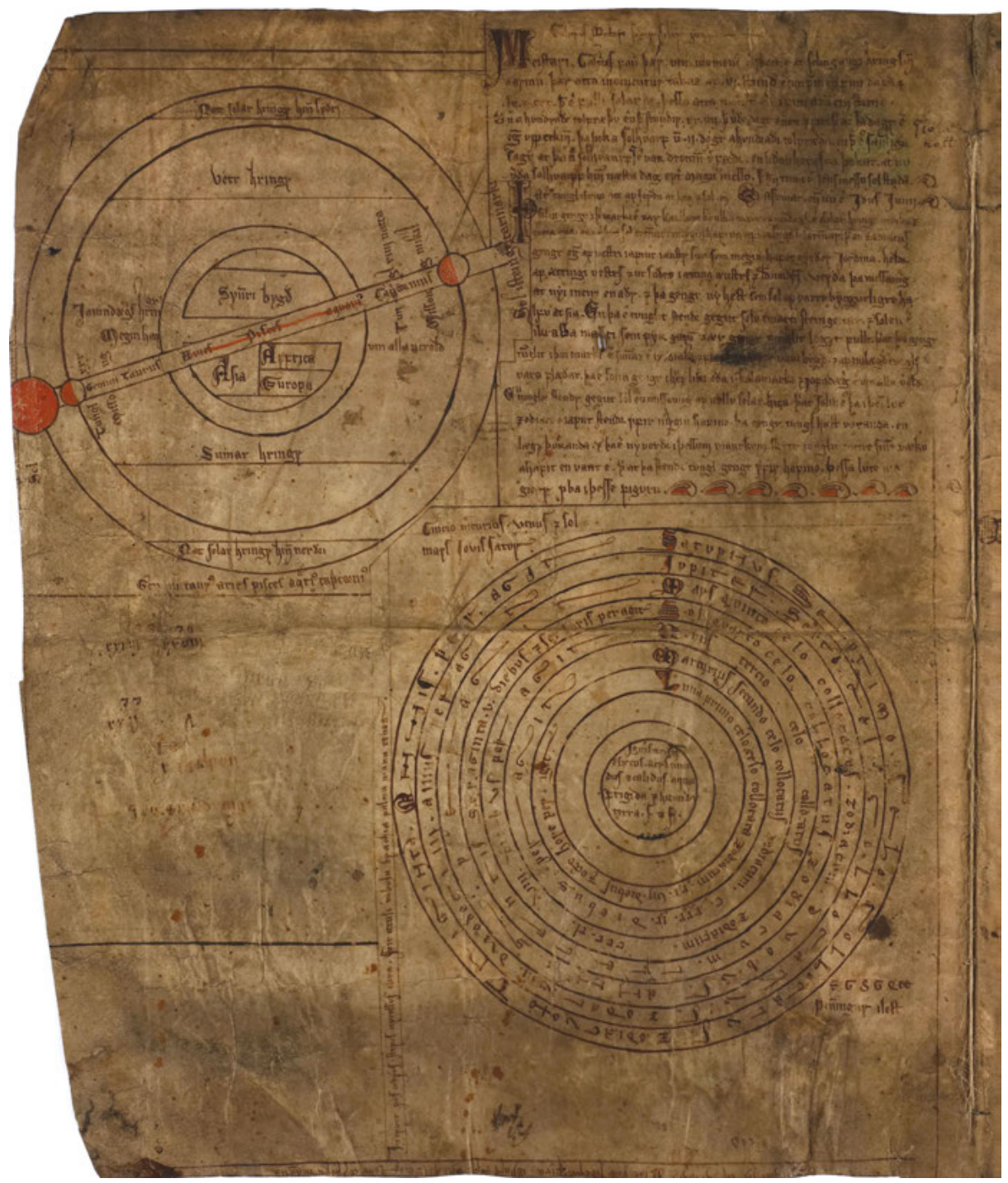

Fig. 20.7: Cosmological diagrams and a Latin verse on the Holy Cross, facing the plan of Jerusalem on the opposite folio. Icelandic manuscript fragment, early fourteenth century (AM 736 | 4to, fol. 1r), The Arnamagnæaen manuscript collection, Copenhagen. 
The idea that the cross of the Lord being crafted from four noble species of wood seems to have developed independently from the legends of the miraculous wood grown from the paradisiac seeds. Rather, it seems to originate from exegetical glosses found in early medieval authors such as John Chrysostom, Gregory of Tours, and the Venerable Bede. To meditate Christ's suffering on the cross and its universal implications, the cross is associated with four woods prominently figuring in the Bible and endowed with symbolic significance. The cedar, which cannot rot, makes up the foot and signifies the eternal validity of Christ's redemptive sacrifice. The upright beam is made from the perfumed cypress, which has conservational qualities and stands for the incorruptibility of Christ's body. The crossing beam is made from a palm tree, whose branches are used as signs of victory and hence indicate Christ's triumph over death. Finally, the titulus with Pilate's trilingual inscription is made from olive to indicate the eternal peace that is the consequence of Christ's sacrificial death. ${ }^{43}$

The thought of the four distinct woods of the cross certainly reflects some monastic, meditational practice. In the fourteenth century, however, it seems to have spread also in the form of narrative folklore. This is not least because Jacobus de Voragine mentions the idea in his extremely widespread Legenda aurea (1260s). In turn, this text was cited by Sir John Mandeville, the alleged author of the popular and muchtranslated Book of Marvels and Travels (1360s). Both Jacobus de Voragine and Mandeville quote an mnemotechnical verse similar to the one found in AM 736 I 4to, however a little more concise: In cruce sit palma, cedrus, cypressus, oliva. ${ }^{44}$

The bifolio AM 736 I 4to contains yet another reference to the Holy Cross. On the verso of the same leaf as the Jerusalem map, a description of Jerusalem was added around $1350 .{ }^{45}$ This short text is taken from the so-called Leiðarvísir, the twelfth-century itinerary describing how to travel from Iceland to Jerusalem. ${ }^{46}$ Here, the Church of the Holy Sepulchre and the site of Golgotha are described with careful attention to the precise site of the cross. Long gone, the stones still testify to its presence - the blood that flowed from the cross can still be seen on the rock, and the rift into which it was inserted is still visible. The absence of the wood of the cross in this short text contrasts with the verse on the preceding folio, insisting on its manifold, meaningful material substance.

43 Anton Legner, Reliquien in Kunst und Kult: Zwischen Antike und Aufklärung (Darmstadt: Wissenschaftliche Buchgesellschaft (WGB), 1995), 76-7.

44 Jacobus de Voragine mentions the verse in his account of the finding of the Holy Cross, Jacobus de Voragine, The Golden Legend: Readings on the Saints, 2 vols, ed. and trans. William Granger Ryan, Princeton NJ: Princeton University Press, 1993, vol. 1, 278; whereas Mandeville quotes it in his description of Jerusalem; Sir John Mandeville, The Book of Marvels and Travels, ed. Anthony Bale, Oxford World Classics, Oxford: Oxford University Press, 2012, 8.

45 Kedwards, "Cartography and Culture in Medieval Iceland," 67.

46 Cf. Chapters 11 (Denys Pringle), 203-6, 12 (Stefka G. Eriksen), 218-43, and 21 (Mikael Males), 470. 


\section{Prophetic Wisdom, Salvation History and the End of the World}

As we have seen above, the legend of the Holy Cross in AM 544 4to (Hauksbók) culminates, so to speak, with the Jerusalem map at fol. $19 r .{ }^{47}$ Given that Jerusalem is one main site of this narrative and that the legend puts heavy emphasis on the cross' potential for universal salvation, the presence of the symbolic Jerusalem map with its cruciform street grid seems an appropriate figure for the message communicated in this tale. On the folio after the map, another narrative follows; the Eddic poem Voluspá (text no. 24). ${ }^{48}$ This famous mythological poem, which traditionally has been considered a major source for our knowledge about pagan beliefs in the Old Norse world, appears at first sight to be out of context. However, in the third quire of AM 544 4to, Voluspá and the legend of the Holy Cross clearly mirror each other, and the Jerusalem map separating them reflects to a certain extent the content of both texts. ${ }^{49}$

Voluspá presents the fate of the world from the creation until its apocalyptic end and the coming of a new and better world. Its protagonists are the pantheon of the pre-Christian North. Nevertheless, the poem is largely shaped and structured by Christian culture and the Christian master narrative of salvation history. ${ }^{50}$ The tale is told as a visionary prophecy, put forward by a volva, a sage prophetess in the Old Norse mythological universe. As Gro Steinsland has shown, the figure of the volva is fundamentally moulded on the sibyls of the Antique world, and Voluspá seems to be directly influenced by the apocryphal sibylline prophecies. ${ }^{51}$ From patristic times onwards, the sibyls were interpreted as pagan counterparts to the Hebrew prophets, said to have predicted the incarnation of Christ and prophesized an apocalyptic end

47 The very short text no. 21, On twelve unseemly things (four and a half lines long) is added by another hand on the very bottom of fol. $18 \mathrm{v}$.

48 The short text no. 23 on fol. 19v regarding conditions of excommunication is added by another hand. Its content is not at all irrelevant to the issue of true religion and inclusion in the Christian oikumene which seems to be one main theme of the compilation, but will not be considered particularly in this context.

49 Karl G. Johansson makes a similar claim in his recent articles on Hausbók, see Johansson, “The Hauksbók" and Karl G. Johansson, "Compilations, Collections and Composite Manuscripts: Some Notes on the Manuscript Hauksbók," in RE:writing. Medial Perspectives on Textual Culture in the Icelandic Middle Ages, ed. Kate Heslop and Jürg Glauser (Zürich: Chronos, 2018).

50 See the following four articles in The Nordic Apocalypse: Approaches to Voluspá and Nordic Days of Judgement, ed. Terry Gunnel and Annette Lassen (Turnhout: Brepols, 2013): Kees Samplonius, “The Background and Scope of Voluspá:” 113-45; Gro Steinsland, "Volluspá and the Sibylline Oracles with a Focus on the "Myth of the Future'” 147-60; Karl G. Johansson, "Volluspá, the Tiburtine Sibyl, and the Apocalypse in the North:” 161-84; and Pétur Pétursson, "Manifest and Latent Biblical Themes in Voluspá:” 185-201.

51 Steinsland, "Voluspá and the Sibylline Oracles”. See also Chapter 4 (Bjørn Bandlien), 74-5. 
of time. The collection of Christological and eschatological prophesies supposedly of sibylline origin, but in reality authored by early Christian apologists, was well known in the Middle Ages, notably through the Sibylla Tiburtina, "one of the most popular, widespread and influential apocalyptic texts of the medieval period." 52 Sibylline prophecies were quoted by early medieval authors like Isidore, Bede, and Hrabanus Maurus, and by several chroniclers and compilers in the twelfth and thirteenth centuries, among them the English Benedictine Matthew Paris, who spent some time in Norway in the 1240s. ${ }^{53}$

The Old Norse volva prophesies the coming of a post-apocalyptic, heavenly and universal ruler. In this figure, Gro Steinsland recognizes the pagan god Heimdallr, "a god well fitted for a typological use." ${ }^{54}$ In accordance with the sibylline tradition, the literary fabric of Voluspá shapes an "indigenous" prophecy in which the second coming of Christ, in the guise of Heimdallr, is predicted. In this context, it is particularly interesting that in AM 544 4to (Hauksbók), the "sibylline" volva actually has a counterpart in the Holy Cross Legend, which precedes the Voluspá text. As we saw above, one of the narrative's protagonists is the Queen of Sheba, who recognizes the wood of the cross and predicts Christ's death, resurrection, and its consequences. In the Old Norse text, Sibyl is her name, although "some calls her Saba" [drotning er Sibilla het enn sumir kalla Sába]. ${ }^{55}$ In the medieval reception of the sibyls, the biblical Queen of Sheba is sometimes confused with the legendary Persian sibyl Sambethe or Sabba, seemingly incited by her role as prophetess in the Legend of the Holy Cross. ${ }^{56}$ Matthew Paris is one of the authors echoing this tradition in his rendering of the Sibylla Tiburtina in his Chronica Majora. ${ }^{57}$

There are, thus, two authoritative prophetesses in the third quire of AM 544 4to, one in each of the two narratives sandwiching the Jerusalem map. Both of them present prophecies concerning events of paramount significance for the fate of humankind. In the Holy Cross Legend, Queen Sibilla predicts the crucifixion of Christ and his victory: future events that will sanctify the city of Jerusalem even more than Solomon's ongoing building of Jahweh's temple. As Karl G. Johansson

52 Johansson, "Volluspá, the Tiburtine Sibyl”. See also Anke Holdenried, “Christian Moral Decline: A New Context for the Sibylla Tiburtina (MS Escorial \&.I.3),” in Peoples of the Apocalypse: Eschatological Beliefs and Political Scenarios, ed. W. Brandes (Berlin - Boston: Gruyter, 2016), 321.

53 Holdenried, “Christian Moral Decline," 147. For Matthew Paris, see Chapter 22 (Margrethe Stang), 480-93.

54 Steinsland, "Volluspá and the Sibylline Oracles," 153. Heimdallr, whose name means "the light of the world," has his abode in Heaven (Himinbjorg) and a distinctly different and mystical genealogy than the rest of the Old Norse pantheon.

55 Hauksbók, 185.

56 Holdenried, “Christian Moral Decline,” 55 and 160.

57 Matthew Paris, Chronaca majora, 7 vols, ed. Henry Richard Luard (London: George Belll \& Sons, 1853-1883). 


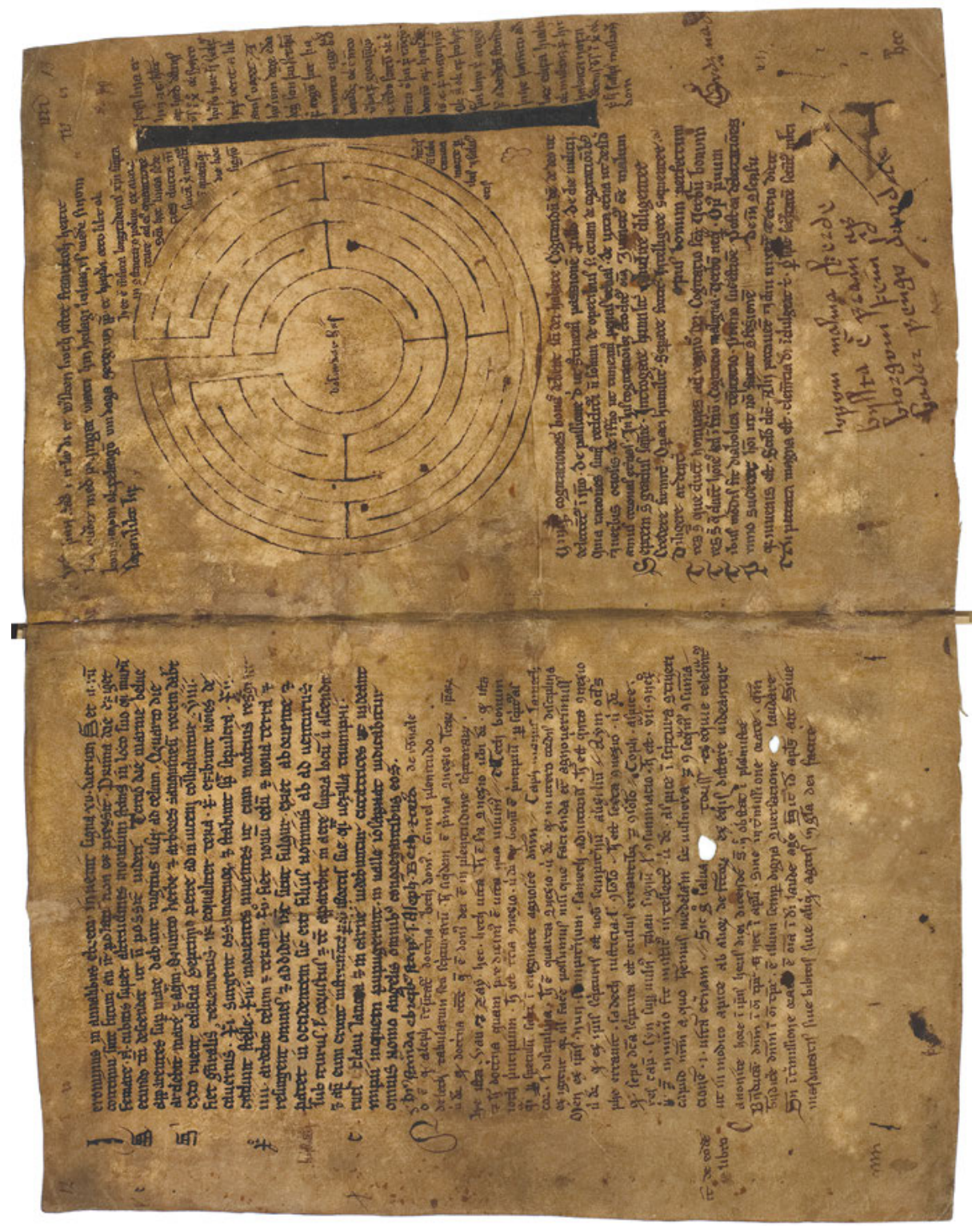

Fig. 20.8: Labyrinth diagram and mensura Christi, one 16th-part of Christ's body length. Icelandic manuscript fragment, early fourteenth century (AM 732b 4to, fol. 7r), The Arnamagnæaen manuscript collection, Copenhagen. 
has pointed out, ${ }^{58}$ the volva in Voluspá foretells the apocalypse and the coming of a new era manifested by the shining architecture of Gimlé:

Sal sér hon standa/ sólu fegra/gulli pakpan/ á Gimlé

par skulu dyggvar/ dróttir byggja/ ok um aldrdaga/ ynðis njóta.

She sees a hall brighter than the sun, thatched with gold, standing on Gimlé.

There worthy people will live and enjoy happiness forever. ${ }^{59}$

The golden hall at Gimlé has often been interpreted as the heavenly Jerusalem - an interpretation which is indeed close at hand in AM 544 4to, where Voluspá is preceded by the heavenly architecture of the circular Jerusalem map (Fig. 20.3) ${ }^{60}$ It is thus tempting to interpret the Jerusalem map in this manuscript as a double image, pointing backward to the Holy Cross Legend as it represents the earthly Jerusalem, and forward to Voluspá as it represents its heavenly, apocalyptic counterpart. ${ }^{61}$

\section{Conclusion: Pace Hierosolime and the Authoritative Measure}

As we have seen, the three Icelandic Jerusalem maps from the fourteenth century are all integrated into manuscripts that compile knowledge about the world, its size and shape, its inhabitants and history, and its divinely revealed destination. In short, the three encyclopaedic manuscripts account for the storyworld of medieval Latin Christianity, the stage on which the drama of salvation history is set. ${ }^{62}$ The Jerusalem maps in the encylopedias may very well be understood as figurative summaries of this storyworld. From the analysis above, it has emerged that the geometric rendering of Jerusalem in these manuscripts echo authoritative knowledge-systemizing diagrams, like the quadripartite circle and the T-O map of the terrarum orbis. At the same time, the maps' representation of architecture alludes to the imagined structures of the

58 Johansson, "The Hauksbók".

59 Voluspá stanza 50, quoted after Paul Schach, "Some Thoughts on Völuspá," in Edda: A Collction of Essays, ed. Robert J. Gledinning and Haraldur Bessason ([Winnipeg]: University of Manitoba Press, 1983), 108.

60 See Schach, "Some Thoughts on Völuspá," 109, with further references.

61 Johansson, "The Hauksbók". Another conspicuous parallel between the Wood of the Cross legend and Voluspá is that both texts include a description of the Tree of Life. As we have seen above, Seth's visions during his visit to the earthly paradise have several elements in common with the vision of the volva. He saw the well from which the four rivers sprang, and the huge Tree of Life above it, extending its branches up to the sky and its roots down to the underworld. In stanza 17 of Voluspá, the volva also describes a huge tree, the world ash Yggdrasil, whose branches stretch to the ends of the world.

62 For the concept storyworld, see Prelude, 6-8. 
heavenly city, anticipating eschatological peace in the countenance of God. The hope for transcendent, eternal peace is enhanced in the AM 544 4to Jerusalem map, where an inscription in the middle of the map reads Pace Hierosolime. The Jerusalem maps in the Icelandic encyclopaedias thus oscillate between the topography of the earthly Jerusalem, figural representation of the world [imago mundi] and eschatological hope.

The three encyclopaedic manuscripts may be read as handbooks for safe navigation in this storyworld, heading for Jerusalem by keeping on the track of faith and steering away from Babylon by renouncing idolatry. A compass for the journey is found on fol. $7 \mathrm{r}$ in AM 732b 4to. To the right of a labyrinth diagram, often considered a representation of the road to Jerusalem accommodating virtual pilgrimage, ${ }^{63}$ there is a broad black line, ca $12 \mathrm{~cm}$ long. According to the Latin and Old Norse text besides it, this line measures a 16th-part of Christ's body length (Fig. 20.8). The reader is advised to have this measure before his or hers eyes during all their days and especially in the hour of death. ${ }^{64}$ The measure of Christ's body hence is the authoritative measure of sanctity, a pledge so to speak, for access to the heavenly city. ${ }^{65}$

As we have learned from scrutinizing the visual peculiarities of the Icelandic Jerusalem maps, they tend to suggest - to an even larger degree than their continental predecessors do - memory machines for (monastic) contemplation. The walls and gates seen from inside the city suggest an architectonical space that is clearly sheltered and enclosed, like the mediational enclosure of the monastic cell - or the enclosure of the well-trained, educated mind, which may contain the whole of the world and the entire history of salvation.

63 Daniel K. Connolly, "At the Center of the World: The Labyrinth Pavement of Chartres Cathedral," in Art and Architecture of Late Medieval Pilgrimage in Northern Europe and the British Isles, ed. Sarah Blick and Rita Tekippe (Boston: Brill Academic Publishers, 2004).

64 "Sancta hec linea sedecies ducta mensuam Christi monstrat; in quocumque die hoc signum cernis non subitanea morte peribis et saluus eris. Pessi lina er hinn 16. hlutr af hæð drottins vars Iesu Christi ok syner hversu har hann sialfr hfur verit a likams vaxt. A hverium dege eða degri sem Pu ser hana fyri augum Per Pa muntu eigi braðdauðr [. . .] Ok sva ok ef Pu hefir Pessi lina fyri augum Per a dauða stundu Pinne, Pa muntu aðlaz eilifa hjialp ok miskun fyri hit haleita nafn drottins vars Iesu Christi ok fyri hans sialfs miskunar dom”, AM 732 b 4to fol. 7r, quoted after Alfræði islenzk II, ed. N. Beckman and Kristian Kålund, Copenhagen: Møllers bogtrykkeri, 1914-1916.

65 On measures of Christ and devotional practices in the late Middle Ages, see Caroline Walker Bynum, Christian Materiality: An Essay on Religion in Late Medieval Europe (New York: Zone Books, 2011), 98 and Emanuele Lugli, The Making of Measure and the Promise of Sameness, (Chicago: University of Chicago Press, 2019), 145-52. 
